\title{
Islamic Education Marketing Discourse From Maslahah Perspective
}

\author{
Sholikah", Fatah Syukur ${ }^{2}$, Mahfud Junaedi ${ }^{3}$ \\ ${ }^{1}$ Institut Agama Islam Nahdlatul Ulama' Tuban, Indonesia \\ 2,3 Universitas Islam Negeri Walisongo Semarang, Indonesia \\ 1sholihah86@gmail.com \\ 2fatahs@gmail.com \\ 3mjunaedi@gmail.com
}

\section{Article History: Abstract:}

Submitted:

19-01-2021

Accepted:

01-04-2021

Published:

18-04-2021
The marketing paradigm has undergone a change from the rational level to the emotional level, and finally, the shift in the spiritual level. Such discourse results in different marketing strategies, especially the marketing applied by both profit and non-profit organizations. Educational institutions, including non-profit organizations, must have a marketing strategy following the spiritual level shift. One spiritual aspect in the marketing of Islamic education is the level of maslahah (utility) applied to all marketing activities. The purpose of this study is to examine educational marketing from a maslahah perspective. This writing is library research with a qualitative descriptive approach-data sources in the form of references related to the study topic. Data analysis was carried out qualitatively, including data reduction, data presentation, and concluding. The results showed that the maslahah of Islamic education customers was the main objective of all Islamic education marketing activities.

Keywords: $\quad$ Marketing, Marketing mix, Education, Maslahah 


\section{Introduction}

The era of globalization ${ }^{1}$ marked by digital advancements signifies that marketing studies play an essential role in business, products, and services. Even now, marketing has become a separate discipline. This means that marketing studies have their own discussion space and have proven their existence in the world of academia and are marked by many studies on marketing.

Nowadays, the marketing ${ }^{2}$ paradigm has experienced a shift in

1 According to Abuddin Nata, the word globalization seen from the point of view of actually still has problems due to the reality and subjectivity of the use of the word, however globalization can simply be shown in the form of scale expansion, regional development, and acceleration of the influence of interregional flows and patterns in social interactions. Abuddin Nata, Kapita Selekta Pendidikan Islam, (Bandung: Angkasa, 2003), 183

2 Marketing is a social and managerial process in which individuals and groups get their needs and wants by creating, offering and exchanging something of value to one another. See, Philip Kotler and Gary Amstrong, Principles of Marketing, 12th ed. (USA: Pearson Prentice Hall, 2008). 5 orientation from time to time. This shift was recognized by the father of international marketing, Philip Kotler, based on market behavior analysis. We are shifting the marketing orientation from product-centric marketing ${ }^{3}$ to consumer-oriented marketing 4 to value-driven ${ }^{5}$

3 In other studies, this orientation is called the rational level, meaning that this level relies on the power of logic and scientific concepts by using a number of marketing tools, such as segmentation, targeting, positioning, marketing mix, branding, and so on. So that the marketing strategy used focuses on product functionality. See, Ratih Tresnati and Nina Maharani, "Kajian Tentang Strategi Pemasaran Syariah Dalam Penguatan Daya Saing UKM Menghadapi AEC 2015 Di Indonesia," Proceedings SNEB 2014, 2015, 1-11.

4 This marketing orientation is at the emotional level, meaning that marketers' understanding of customer emotions and feelings is very important. Some marketing concepts on an emotional level include experiential marketing and emotional branding. See, Domenico Consoli, "A New Concept of Marketing: The Emotional Marketing," BRAND. Broad Research in Accounting, Negotiation, and Distribution 1, no. 1 (2010): 1-8.

5 While this value-driven marketing orientation is at the spiritual level of marketing, meaning that marketing practices 
marketing 6 . This shift in marketing orientation can be interpreted from using logical language to the language of taste to heart language. This difference in direction certainly has an impact on the marketing strategies used by profit $^{7}$ and non-profit ${ }^{8}$ organizations.

are returned to essential functions and carried out with a strong morality, including the principles of honesty, empathy, love, and care for others. Tresnati and Maharani, "Kajian Tentang Strategi Pemasaran Syariah Dalam Penguatan Daya Saing UKM Menghadapi AEC 2015 Di Indonesia."

6 Muhammad Anwar Fathoni, "Konsep Pemasaran Dalam Perspektif Hukum Islam," Jurisdictie: Jurnal Hukum Dan Syariah 9, no. 1 (2018): 128-46.

7 Profit in this case is an organization established with the aim of obtaining an income and profit for each member of the organization in the field of goods or services, for example companies, firms, and others. See, Wiwin Widiasih, "Studi Komparasi Implementasi Manajemen Proses Bisnis Pada Lembaga Profit Dan Nonprofit," Seminar Nasional Terpadu Keilmuan Teknik Industri, 2015, 1-6.

8 Meanwhile, non-profits are organizations that are founded with the main objective of attracting the attention of the public, groups or certain groups of people and excluding income, for example education, hospitals, and others. Look at Widiasih.
Educational institutions of a non-profit ${ }^{9}$ must also manage their marketing strategy intelligently to remain during competition. ${ }^{10}$ That is because marketing activities will facilitate providing information to customers about the quality of education to meet the needs and according to the customer's desired. ${ }^{11}$ Information about education through targeted marketing to the company will shape the image ${ }^{12}$ of good ${ }^{13}$ about the education.

9 Buchari Alma, Manajemen Corporate dan Strategi Pemasaran Jasa Pendidikan; Fokus pada Mutu dan Layanan Prima, (Bandung: Alfabeta, 2009), 30

10 Subhan Afifi and Edy Susilo, "Pengembangan Komunikasi Pemasaran Sekolah," Ilmu Komunikasi 13, no. 3 (2014): 277-86.

11 Sri Nastiti Andharini, Dewi Nurjannah, and Eka Kadharpa, "Komunikasi Pemasaran Jasa Pada Pendidikan Tinggi Di Malang," Seminar Nasional Dan Gelar Produk, 2016, 585-91.

12 Image is a representation related to the symbol, perception, and behavior of the organization that implies to the public about a particular organization related to abstract matters. See, Nurul Qomariah, "Pengaruh Kualitas Layanan Dan Citra Institusi Terhadap Kepuasan Dan Loyalitas Pelanggan (Studi 
Educational marketing is necessary to convince the public as customers that the educational services provided by educational institutions are relevant to their needs. It is also essential to broadly introduce the services provided by educational institutions to customers; third, customer demands for high-quality education; fourth, there is competition among competitors in education, which is increasingly attractive. ${ }^{14}$ So

Pada Universitas Muhammadiyah Di Jawa Timur)," 2012. 191. Thus the reputation of the institution also depends on the image built (see at Dean Kazoleas, Yungwook Kim, and Mary Anne Moffitt, "Institutional Image: A Case Study," Corporate Communications: An International Journal 6, no. 4 (2001): 205-16, https://doi.org/10.1108/EUM00000 00006148.

13 A good image is when an institution is able to create public understanding, have public

confidence, have public support, have a public corporation. See at Neny Yulianita, Dasar-Dasar Public Relation, (Bandung: Pusat penerbitan Bandung, 2005), 47

14 Fatkuraji, "Pengembangan Model Manajemen Pemasaran berbasis Layanan Pendidikan Madrasah Tsanawiyah Swasta di Kota Semarang". Disertasi Program Pascasarjana Program Studi Manajemen that educational marketing must be more innovative in providing educational services and providing satisfaction to customers.

In the face of shifting marketing orientation, Islamic educational institutions must have creativeand innovativeefforts in this century. Education providers must explore the uniqueness and advantages of their institutions so that users of education services are increasingly needed and interested. What needs to be done to attract potential customers is marketing ${ }^{15}$, which is selling educational services as they are and approaching the approach according to customer desires and satisfaction, considering the suitability of service products to believed spiritual values, and providing maslahah for customers. An

Kependidikan Universitas Negeri Semarang, 2016, 2

15 Marketing strategy is a comprehensive, integrated and unified plan in the field of marketing that provides guidance on the activities to be carried out in order to achieve the marketing objectives of a company. See at Sofjan Assauri, Manajemen Pemasaran, (Jakarta: Raja Grafindo, 2007), 168-169 
educational institution that wants to be successful and continue to exist in the future in facing competitors, ${ }^{16}$ must practice marketing continuously following the shifting of marketing paradigms that occur from time to time for the benefit of customers.

Customer problem is significant to pay attention to as it is related to educational marketing itself, namely to attract customer interest and trust in the long time. ${ }^{17}$ If customers feel that their wants and needs are well fulfilled, they will automatically become regular customers even though they have become alumni.

16 Competition in this case is no longer related to the efficiency of education delivery, but structurally it has become common sense if the chosen educational institution is the one that has advantages in almost all aspects, including input, process and output. See, Nurtanio Agus Purwanto, "Strategi Bersaing Dalam Bisnis Pendidikan," Manajemen Pendidikan VII, no. 01 (2011): 9-16.

17 Fakhrurozi, "Strategi Pemasaran Jasa Pendidikan Dalam Meningkatkan Citra Pendidikan Islam," Jurnal Pemikiran, Riset Dan Pengembangan Pendidikan Islam 7, no. 2 (2012): 207-232.
Maslahah in Islam means an action that can forever produce good or benefit, which applies to most social and individuals.18 This definition states that the level of benefits and benefits is the top priority in all activities. Based on this understanding, educational institutions really need to pay attention to the maslahah and mafsadat levels of all marketing activities, both from the analysis aspect to the marketing evaluation stage carried out and the applied marketing mix.

Studies on the marketing mix have been widely carried out in both modern educational institutions and Islamic education. These studies give rise to various kinds of marketing mix concepts offered by researchers. The difference in previous researchers' concepts is very likely due to the different approaches and methodologies used. Therefore, on this occasion, the author will present a marketing mix study from the perspective of maslahah. This

18 Muhammad Thâhir bin 'Asyûr, Maqâshid asy-Syarîh alIslâmiyah, (Yordania, Dâr anNafâ"is: 2001), 278 
study begins with a question, is there marketing education in an Islamic perspective, especially maslahah? If so, how is the marketing from the perspective of the maslahah? So that you will get an overview of the marketing mix from the maslahah perspective. This study examines the conventional marketing mix, the marketing mix in Islam, the concept of maslahah in a theoretical review, and the marketing mix from the perspective of maslahah.

\section{Method}

This study is descriptive qualitative research related to the marketing of Islamic education. This study is also library research where the data source used is secondary data in scientific articles and books following this study. This study's focus on the marketing mix in the maslahah perspective includes the conventional marketing mix, the Islamic marketing mix, the maslahah concept in a theoretical review, and the educational marketing in the maslahah perspective. This study is expected to provide an overview of the marketing mix from the standpoint of maslahah in Islamic education institutions as material for considering the direction of educational marketing management policies in this era. This study's data analysis technique is qualitative analysis, which includes data reduction, data presentation, and conclusion drawing. ${ }^{19}$

\section{Result}

Previous research conducted by researchers on educational marketing is as follows: Research of Hani Hamid and Hamzah Nabiyah ${ }^{20}$ with the title "atTawajjuh at-Taswiqy laday Muassisat at-Ta'lim al-'Aly fi alUrdun; Dirasah Tahliliyyah Maidaniyyah." This research states that internal marketing is essential applied in higher education institutions in Urdun. Internal marketing is conducted by including the academic community in the

19 Matthew B. Miles and A. Michael Huberman, "Qualitative Data Analysis", 3td Edition, (London: Sage Publication, 1984), 8

20 Hani Hamid and Hamzah Nabiyah, "at-Tawajjuh at-Taswiqy laday Muassisat at-Ta'lim al-'Aly fi al-Urdun; Dirasah Tahliliyyah Maidaniyyah", al-Majallah alUrduniyyah fi Idaroh al-A'mal, Vol. 3, No. 3, 2007, 296-323. 
workshop following their respective expertise. In addition, higher education institutions require the promotion only through print media and electronic media, so that students' needs and desires in obtaining information can be easily accessed through electronic media.

The study from Muhammad Hamid Radli and Ali Jihad Ibrahim with the title "Waqi' Taswiq Judah al-Khidmat at-Ta'limiyyah; Dirasah atTathbiqiyyah fi Kulliyyah alMa'mun/al-Jami'ah fi Baghdad".21 This study focuses on the quality of college services and evaluation of services provided to customers such as students, employees, and alumni. This study states that the quality of education services has a significant attachment to students, employees, and alumni off school.

Messikh Ayoub and Lahdlari Sholih conducted a

21 Muhammad Hamid Radli and Ali Jihad Ibrahim under the title "Waqi' Taswiq Judah al-Khidmat atTa'limiyyah; Dirasah atTathbiqiyyah fi Kulliyyah alMa'mun/al-Jami'ah $\mathrm{fi}$ Baghdad", Majallah al-Idarah wa alIqtishad, Vol. 85, 2010, 63-111 study 22 entitled "at-Taswiq alMashrifi fi Algeria (Dirasah Halah Bank al-Fallahah Wa atTanamiyyah ar-Rifiyyah Badr SKIKDA 744)". This study states that despite the lack of independent services in banks for marketing due to the focus on other policies, the bank has a good trend towards modern marketing concepts, through the adoption of expanded, mixed marketing, and also taking advantage of the technological development and information revolution it has gained in banking to be more flexible, dynamic, and speed in providing services.

The study conducted by of Yusuf Hajim Sulthon and Hasyim Fauzi ${ }^{23}$ with the title" Taswiqu Khidmati at-Ta'lim al-Jami'y wa Mulaimatiha ma'a Ihtiyajati az-Zabun" states that educational marketing activities will not succeed

22 Messikh Ayoub and Lahdlari Sholih, "at-Taswiq al-Mashrifi fi Algeria (Dirasah Halah Bank alFallahah Wa at-Tanamiyyah arRifiyyah Badr SKIKDA 744)", Majallah al-Bahits al-Iqtishady, Vol. 4, December 2015, 94-109

23 Yusuf Hajim Sulthon and Hasyim Fauzi, "Taswiqu Khidmati at-Ta'lim al-Jami'y wa Mulaimatiha ma'a Ihtiyajati az-Zabun", Majallah al-Idaroh wa al-Iqtishod, Vol. 65, 2007, 112-154. 
without knowing

the

customer's

wishes. Once

understood the customer's wishes, the institution needs to create marketing management that matches its target market. If it does not meet the target market's needs, then the institution will suffer a setback and cannot attract its customers' trust.

Badr Mabruk al-'Atibi24 wrote Taswiq al-Khidmat alJami'iyyah wa dauruhu fi tahsini al-qudroh at-tanafisiyyah $l i$ alJami'ah as-Su'udiyyah". This study states that the most crucial university service is in the learning process. If all academic communities improve the quality of services in their learning process, then the university will be in high demand by the community. In other words, internal marketing at universities is highly recommended in improving competitiveness with competitors.

24 Badr Mabruk al-'Atibi, "Taswiq al-Khidmat al-Jami'iyyah wa dauruhu fi tahsini al-qudroh attanafisiyyah li al-Jami'ah asSu'udiyyah", Mutathollib takmily linaili darojati al-dukturoh fi Qismu idaroh at-tarbiyyah wa at-takhthith fi kulliyat at-Tarbiyyah fi Jami'ah Ummu al-Quro as-Su'udiyyah, 2015.
Jonathan

A.J.'s research Wilson ${ }^{25}$ published in the Journal of Islamic Marketing under the title "The new wave of transformational Islamic Marketing; Reflection and Definitions" discussed a unique, reflective, and important Islamic marketing phenomenon to discuss. This is because Islamic marketing is based on faith and Muslim activities worldwide in terms of business and corporate management related to social affairs. How to understand the phenomenon of Islamic marketing and make people switch from conventional marketing to Islamic marketing?

Research AG Tahir, SAA Rizvi, MB Khan, Farooq Ahmad" ${ }^{26}$ with the title "Keys of Educational Marketing." This study found that physical facilities and excellence are considered the most critical marketing strategies, whereas

25 Jonathan A.J Wilson, "The New Wave of Transformational Islamic Marketing Reflections and Definitions," Journal of Islamic Marketing 3, no. 1 (2012): 5-11.

26 A.G Tahir, S.A.A Rizvi, and Farooq K. Ahmad, "Keys of Educational Marketing," Journal of Applied Environmental and Biological Sciences 7, no. 1 (2017): 180-87. 
price and premium are considered the least important. New and modern programs, adequate locations, highly qualified faculties (people), educational exhibitions (promotions), and physical facilities are examples of educational marketing strategies that can attract students.

Ahmad Azrin Adnan Research" ${ }^{27}$ titled "Theoretical Framework for Islamic Marketing: Do We Need a New Paradigm? "I don't want to This research yields the finding that marketing concepts and strategies should have the ability to understand both the needs and desires of consumers following the trends of the 21st-century marketing paradigm that are changing from product-centric to consumer-centric. In addition, there are three arguments based on the public's point of view about Islamic marketing: a. the definition of marketing, in general, cannot be compared to Islam which is of faith; $b$. Islamic marketing leads more

27 Ahmad Azrin Adnan, "Theoretical Framework for Islamic Marketing: Do We Need a New Paradigm?" International Journal of Business and Social Science 4, no. 7 (2013): 157-165. to marketer behavior, not consumer behavior; c. that is because the concept of Islamic marketing is still reflected in conventional marketing related to Islam.

Ali Akbar Jakfari Research ${ }^{28}$ with the title "Islamic Marketing: Insights from a Critical Perspective." This research resulted in a thought about incorporating Islamic values in marketing that have been value-free. So in this study, the authors invite Muslim practitioners to formulate an Islamic marketing concept to criticize the idea of marketing that developed during this time and seem to make it lawful all means to meet the target market.

Previous studies both in Indonesia and abroad, especially on education marketing have been carried out and resulted in several recommendations, including a) the focus of research is internal marketing in tertiary institutions; b) focus on developing the marketing of Islamic banking services; c)

28 Aliakbar Jafari, "Islamic Marketing: Insights from a Critical Perspective," Journal of Islamic Marketing 3, no. 1 (2013): 22-34, https://doi.org/10.1108/175908312 11206563. 
customer service based educational marketing educational marketing; d) strategies are carried out differences in the directly and indirectly to characteristics of Islamic customers, accompanied by marketing with conventional analysis of supporting and marketing; e) the phenomenon inhibiting factors and solutions of Islamic marketing and making people switch from conventional marketing to Islamic marketing; f) analysis of the marketing mix for 7P education in tertiary institutions; g) marketing strategy following the trend of the 21st-century marketing paradigm; h) education marketing strategy model in SMK, namely internal, external, and interactive marketing; d) there are 2 steps in educational marketing management in STIKES, namely marketing strategies including market identification, marketing targets, and positioning. Meanwhile, marketing tactics are focused on product differentiation; i) marketing management at Madarasah Ibtidaiyyah Negeri uses the functions of plan, organizing, actuating and controlling; j) analysis of the education marketing mix specifically on the aspect of promotion; $\mathrm{k}$ ) analysis of the marketing mix in educational institutions to these inhibiting factors.

Based on previous studies, some of the recommendations presented include Islamic marketing in the context of economics and education in general or refer to conventional marketing and there has been no research on marketing mix from the perspective of maslahah theory. Therefore, this study focuses on the marketing mix in the perspective of maslahah theory. So that the final result of this study will produce a marketing mix concept based on maslahah (utility) theory and can be used by Islamic education institutions in designing their marketing strategies and can compete with other institutions without having to leave the essence of the educational institution.

\section{Conventional Marketing Mix}

The marketing mix dominates the marketing concept. The marketing mix uses marketing variables that marketers can control and use using a complete $7 \mathrm{P} ; 1$ ) to achieve the intended 
marketing goals or target market. This marketing mix was first introduced by Neil $\mathrm{H}$. Borden, a professor of Marketing and Advertising at Harvard Business School. The marketing mix concept introduced has twelve elements: Product Planning, Pricing, Branding, Channel of Distribution, Personal Selling, Advertising, Promotions, Packaging, Display, Servicing, Physical Handling, and Fact Finding and Analysis. ${ }^{29}$ Then Frey divides the marketing variables into two elements, namely offer (Product Planning, Pricing, Branding, Packaging, and Service) and methods and tools (Channel of Distribution, Personal Selling, Advertising, Promotions, and Publicity). In 1962 Lazer and Kelly ${ }^{30}$ suggested three marketing mix elements: the goods and services mix, the distribution mix, and the communications mix.

29 Neil H. Borden, "The Concept of Marketing Mix", Journal of Advertising (1984): 7-12

30 W. Lazer, \& E. K Kelly, Managerial Marketing: Perspectives and Viewpoints, (IL: Richard D. Irwin, 1962),
McCarthy ${ }^{31}$ reconstructed Borden's marketing mix concept into four elements: Product, Price, Promotion, and Place. Then Magarth ${ }^{32}$ added three other elements, namely personnel, physical facilities, and process management. Vignalis and Davis ${ }^{33}$ suggest adding $S$ (Service) to the marketing mix. Goldsmith ${ }^{34}$ argues that there must be $8 \mathrm{P}$ (product, price, place, promotion, participants, physical evidence, process and personalization). Moller ${ }^{35}$ (2006) presents an up-to-date overview of the current position in the debate surrounding the marketing

31 E. J. McCarthy, Basic Marketing, (IL: Richard D. Irwin, 1964),

32 A. J. MaGrath, "When Marketing Services, 4Ps Are Not Enough," Business Horizons, 29(3), 1986, 45-50.

33 C. Vignali, \& B. J. Davies, “The Marketing Mix Redefined and Mapped - Introducing the MIXMAP Model," Management Decision, 32(8), 1994, 11-16.

34 Goldsmith R. E., "The Personalised Marketplace: Beyond the 4Ps," Marketing Intelligence and Planning, 17(4), 1999, 178-185.

35 K. Möller," The Marketing Mix Revisited: Towards the 21st Century Marketing by E. Constantinides," Journal of Marketing Management, 22(3), 2006, 439-450. 
mix as the dominant marketing paradigm and marketing management tool by looking at the academic views of the five sub-disciplines of marketing management (consumer marketing, relationship marketing, services marketing, retail marketing and industrial. marketing) and new marketing (E-Commerce).

The marketing mix used by a particular agency will vary according to its resources, market conditions, and changing customer needs. ${ }^{36}$ The importance of several elements in the marketing mix will vary at one point in time. So, agencies on one element of the marketing mix must consider their impact on other elements.

\section{Islamic Marketing Mix}

Islamic marketing mix cannot be separated from the meaning of Islamic marketing, namely: "The process and strategy (Hikmah) of fulfilling need through Halal (Tayyibat) products and services with the mutual consent and welfare

36 S. P. Low, \& H. M. Kok, "Formulating A Strategic Marketing Mix for Quantity Surveyors," Marketing Intelligence \& Planning, 15(6), 1997, 273-280.
(Falah) of both parties i.e. buyers and sellers to achieve material and spiritual wellbeing in the world here and the hereafter." 37

According to Aloem and Haque, the definition emphasizes the importance of meeting the needs of the world and the hereafter in the concept of Islamic marketing. The Islamic marketing concept must represent companies' interests that want to get optimal benefits but must still pay attention to the halalness of the products and services offered to consumers. There must be a balance between the welfare of employees and shareholders.

Alom and Haque, ${ }^{38}$ put forward the basic principles in Islamic marketing, including strategy (wisdom) $)^{39}$, need ${ }^{40}$, halal

${ }^{37}$ Mahabub Alom and Shariful Haque, "Marketing: An Islamic Perspective Alom \& Haque," World Journal of Social Sciences 1, no. 3 (2011): 71-81.

38 Alom and Haque.

39 Wisdom in this case is closer to the term wisdom strategy (wisdom) which will guide a person moderately to meet one's needs and in spending whatever is left for charitable purposes. That is why humans should not forget the Book and wisdom because Allah has 
(thayyibat) ${ }^{41}$, consent 42 and

mutual welfare

entrusted them with the noble task of guiding the world. They should also not forget good and truth and abstain from injustice and other evil behavior instead of directing the world and humans to the Right Way. See Alom and Haque.

40 Islamic marketing is based on needs, meaning that it consumes according to their needs and marketing promotion activities must not be an art of deception or deceiving consumers and only for a noble purpose, it will provide clear information for the benefit of the people as Surah 17:29 is as follows:

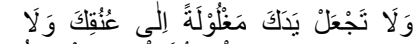

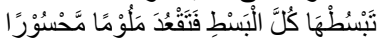

"And do not make your hands shackled around your neck and do not (also) stretch out too much (very generously) later you will become despicable and regretful"

${ }^{41}$ Halal here as Surah 2: 168

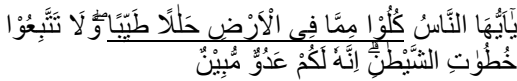

"O people! Eat of the clean and good (food) that is on earth, and do not follow in the steps of Satan. Really, the devil is a real enemy to you ".

42 Agreement in this case means that the exchange must be operated with the free will of the buyer and seller and free from pressure, fraud, and even fraud. See Alom and Haque, "Marketing: An Islamic Perspective Alom \& Haque." The agreement between the two parties is based on the verse of alQur'an 4:29

O you who believe, do not eat each other's wealth in an evil way, except by way of commerce that is (falah) ${ }^{43}$. Naveed Ahmad defines Islamic marketing as a belief in the maximization of values built on justice and integrity for humanity's welfare ${ }^{44}$. This definition emphasizes the difference between conventional marketing and Islamic marketing on the importance and norms of a series of marketing activities.

Based on some of the definitions above, the author

consensual among you. And don't kill yourselves; Indeed, Allah is Most Merciful to you.

43 Falah is a comprehensive and worldly concept. This term denotes the welfare of all sides of this life as well as the hereafter. This implies that the attainment of material well-being must be in a manner consistent with the attainment of welfare in the more important and eternal phase of human life which is the hereafter. See Siddiqi in Alom and Haque. The concept of falah is as in the verse of al-Qur'an 2: 201

$\ldots$ and among them there are people who pray: "O Our Lord, give Us goodness in the world and goodness in the hereafter and protect Us from the torments of hell".

44 Naveed Ahmad, dkk., "Impact of Islamic Fashion Marketing on Islamic Marketing: A Case Study of Pakistani Women's", Kuwait Chapter of Arabian Journal of Business and Management Review, Vol. 3. No. 5, 2014, 66-72 
can conclude that Islamic marketing is an activity of running a business from planning, creation to offering to consumers based on values, principles, and the basis for marketing based on Islamic law and avoiding actions prohibited Islamic law.

Nurhazirah Hashim and Muhammad Iskandar Hamzah have formulated the marketing mix in Islam by integrating the 7P's marketing concept with Islamic teaching. The seven elements of the marketing mix are then integrated with the 7Ps of Islam introduced by Jonathan Wilson ${ }^{45}$ : Pragmatism ${ }^{46}$, Pertinence ${ }^{47}$,

45 Jonathan Wilson, "Looking at Islamic marketing, branding and Muslim consumer behavior beyond the 7P's," Journal of Islamic Marketing, Vol. 3 No. 3, 2012, 212-216.

46 Pragmatism and Product referred to here is how to choose the products and services to be sold, according to human needs. This refers to the attitude of the Prophet Muhammad. who choose to sell products that are needed by all humans.

47 Pertinence and Promotion means that promotional activities must be precise and in accordance with what they are. Islam prohibits promoting products and services by making excessive promises so that consumers are not frustrated when
Palliation 48, Peer 49 , Pedagogy $5^{50}$, Persistent ${ }^{51}$, and Patience ${ }^{52}$.

In the following research conducted by Samir Abuznaid, the Islamic marketing mix has added $7 \mathrm{P}$ elements with two elements that are following Islam, namely "Promise"53 and

things do not match their expectations.

48 Palliation and Price is meant to provide a price that is acceptable to the market, by giving a discount or the like. Rasulullah Saw. always sells merchandise at a price that consumers always accept.

49 Peer-support and people, in this case, is maintaining customer relationships and satisfaction. Abul Hasan, et. al., "Islamic Marketing Ethics and Its Impact on Customer Satisfaction in the Islamic Banking Industry", JKAU: Islamic Econ, vol. 21, no. 1 (2008), 27-46.

50 Pedagogy and Physical environment is to familiarize oneself and stakeholders to be transparent in all respects to maintain integrity so that all information related to products and services sold is obtained by consumers.

51 Persistence and Process or persistence and process are two things that must be done together.

52 Patience and Place, Prophet Muhammad SAW. in this case the order is not to hide anything for the customer during the transaction. This is a form of Islamic teachings that always promote and protect the rights and interests of consumers.

53 This agreement is made by both the seller and the buyer, so that there is mutual agreement or 
"Patient"54, so that it becomes 9P, namely Product, Price, Place, Promotion, Physical evidence, People, Process. Promise, and Patient. Two elements added by Samir based on commercial principles practiced in Islam are First, submission to God's moral order and second, empathy and compassion for God's creation which implies refraining from harming others and thereby preventing the spread of practices are not ethical.

The addition of these two elements is based on the results

pleasure. As explained in the AlQur'an (5: 1):

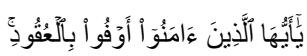

Meaning: O you who believe, fulfill that aqad-aqad.

Aqad-aqad in marketing, for example khiyar. This Aqad khiyar gives the buyer the right to return the purchased goods if there is damage as the agreement has been agreed by the seller and the buyer. So that no one feels loss with this aqad khiyar. Because in Islam, the promises given must be kept and respected. See, Samir Abuznaid, "Islamic Marketing: Addressing the Muslim Market," An - Najah Univ. J. Res. (Humanities). Vol. 26(6), 2012, 1495

54 Patience is an important element in providing service to customers. Because patience is a characteristic of good conversation. As Allah says (41:35 and 16: 127). of research conducted in Muslim market areas. This study's results have practical implications for marketing practitioners and international investors who produce, sell, and market in Muslim and Arab countries and societies. Islamic marketing mix based on value maximization demands empathy and compassion of God's creatures which implies restraint from harming others and preventing the spread of unethical marketing practices.

\section{Concept of Maslahah in Theoretical Review}

Maslahah (usefulness) is the core of all Islamic law tools. All aspects of the rules of the Shari'a are designed by God to be oriented to create benefit for humans. ${ }^{55}$ On that basis, maslahah is always relevant as a basis for consideration of legal istinbâth in all space and time contexts, especially for aspects of certain Islamic laws that have no evidence of the argument. Included in this, is in the context of marketing Islamic education.

55 Amir Syarifuddin, Ushul Fiqh, Jilid 2, Cet. Ke-V, (Jakarta: Kencana, 2011), 220 
The word al-mashlahah, is the singular form of the word al-mashâlih rooted from the word ah-shalâh (goodness) as opposed to al-fasâd (badness/damage), al-ishlâh (repair) versus al-ifsâd (destruction). The word Ashshalâh also means al-ihsân (goodness) and as-silm (peace). ${ }^{56}$ The meaning of maslahah and mafsadah revolves around al-khair wa asy-syarr, an-naf'u wa adhdhârr, and al-hasanât wa assayyi'ât, so etymologically, maslahah is an accumulation of the meaning of goodness and benefit, and mafsadat is the accumulation of purposes of ugliness, danger, and corruption. ${ }^{57}$

The word maslahah in the formulation of urfi according to al-Ghazalî is an effort to realize benefits and avoid harm $^{58}$. According to

56 Ibnu Manzhûr, Lisân al'Arab, (Kairo, Dâr Al-Ma'arif: tt), lihat penjelasan kata shalaha, Jilid. 28, 2479

57 Izzuddîn bin Abdissalâm, Al-Qawâ'id al-Kubrâ; Qawấ'id alAhkâm fì Mashâlih al-Anam, (Damaskus, Dâr al-Qalam: 2000), 7

58 Abû Hâmid al-Ghazalî, AlMustashfâ min 'Ilm al-Ushûl, Jilid. 2, (Beirut, Dâr al- Kutub al-Ilmiyah: 2010), 481. In the explanation of almunasib, al-Ghazalî added:
Izzuddîn bin Abdissalam, maslahah is essentially al-afrah (joy/happiness) and alladzdzah (pleasure/delicacy) and majazi are the causes that can manifest both. Likewise mafsadat, essentially is al-alam (pain) and al-ghumûm (restlessness) and majazi are the causes that can give rise to both. 59

Abu Hamid Al-Ghazalî defines maslahah as an effort to realize benefits by maintaining God's purposes (maqasid asyShari ') and preventing mudharrat which causes neglect of maqasid asy-Shari'. $\quad 60$ According to al-Khawârizmî, maslahah is maintaining maqasid ash-Shari 'by avoiding

"(Maslahah), namely things that can manifest something according to human will from the side of producing (tahshil) and maintaining (al-ibqa '). At-tahshil is an effort to realize benefits, and al-ibqa 'is an attempt to avoid madharrat. Anything worth holding on to, losing it is Madharrat. Automatically, the effort to defend and protect it means avoiding the madharrat. See, Abu Hamid AlGhazalî, Syifấ' al-Ghalîl fì Bayâni asySyabahi wa al-Mukhayali wa Masâlik at-Ta'lîl, (Baghdad, Mathba"ah AlIrsyâd: 1971),159.

59 Izzuddin bin Abdissalâm, Al-Qawố'id al-Kubrâ, Jilid. 1, 18

60 Abû Hâmid al-Ghazalî, 'AlMustashfâ min 'Ilm., 482 
mafsadat from humans ${ }^{61}$. Meanwhile, Ibn Asyûr defines maslahah as the nature of an action that can forever produce good or benefits that apply to most social and personal individuals ${ }^{62}$. Meanwhile, according to alBûthî, are the benefits intended by God for His servants, including the maintenance of religion, soul, mind, descent, and property. ${ }^{63}$ The definitions above, base maslahah normatively on conformity with the orientation of the shari'a regulators (maqâshid asy-syâri ') to realize human maslahah.

Maslahah has existed in the practice of istinbâth law since the time of the Prophet of the Companions. Even the Companions themselves are the main reference for the practice of istinbâth law based on the application of the

61 Muhammad asy-Syaukânî, Irsyâd al-Fuhûl ilâ Tahqî̀ al-Haq min Ilmi al- Ushûl, (Riyâdh, Dâr alFadhîlah: 2006), 990

62 Muhammad Thâhir bin 'Asyûr, Maqâshid asy-Syarîah alIslâmiyah, (Yordania, Dâr anNafâ"is: 2001), 278

63 Muhammad Said Ramadhan Al-Bûthi, Dhawâbith al-Maslahah fî Asy-Syarî'at al-Islâmiyah," (Kairo, Muassasah ar-Risâlah: 1973), 23 principle of maslahah. ${ }^{64}$ This continued to enter the phase of the emergence and development of the schools of fiqh.

Even though it has not materialized as a theoryconceptual building, Abû Hanîfah has elaborated the maslahah principles at the level of practical figh through the concept of istihsân 65 . These various practical fîqh products (furû fîqhiyah) will become the basis for the formulation of the Hanafiyah style ushûl fîqh theory (tarîqat al-fuqaha). 66

During Imam Mâlik there was no definitive formula regarding the theories of legal

64 Abu Hamid Al-Ghazalî, AlMankhûl min Ta'liqât al-Ushûl, (Beirut, Dâr al-Fikr: tt), 353

65 Musthafâ Sa'îd al-Khin, Abhâts Haula Ushûl al-Fîgh: Târîkhuhu wa Tathawwuruh, (Damaskus, Dâr al-Kalâm athThayyib: 2000), 164-166

66 Teorisasi ushûl fígh di kalangan Hanafiyah menggunakan metode juridical induction (al-istiqrâ' al-fîghiyah), yaitu merumuskan teori berdasarkan investigasi dan inventarisasi hasil-hasil dan produk fìh yang telah ada, yang kemudian dikenal dengan corak tharîqatu alfuqahâ. Lihat, Ibnu Khaldûn, Muqaddimah: Târikh Ibnu Khaldûn, Jilid. 1, (Beirut, Dâr Al-Fikr, 2001), 576 
istinbâth, including maslahah. The maslahah element in the istinbâth method is only detected through legal products, fatwa formulations, and his sayings, especially in the al-Muwatha book. ${ }^{67}$

Until the era of Imam Malik, maslahah had not been standardized both theoretically and terminologically. ${ }^{68}$ This is because bookkeeping and standardization of ushûl fîgh theories in a structured and systematic manner only appeared in the era of Imam Shafili, with the birth of arRisâlah. ${ }^{69}$ The emergence of ar-

67 Musthafâ Sa'îd al-Khin, Abhâts Haula Ushûl al-Fîgh, 175

68 This phenomenon cannot be separated from the attitude of Imam Malik and Abu Hanifah who prohibited his students from writing anything that arose from their sayings and fatwas. Abu Hanifah even adamantly rebuked his student Abu Yusuf when he wrote his words, "Did you write everything I said, O Ya 'qub? Really, I feel that what I say today might be different from what I will say tomorrow, and what I say tomorrow might change and be different from what I say the next day. Muhammad Abu Zahrah, Târîkh al-Madzâhib al-Islâmiyah, (Kairo, Dâr al-Fikr al-Arabî: tt), 290.

69 The book of ar-Risâlah introduces the style of tarîqat almutakallimîn which formulates a theory first as a basis for responding
Risâlah became the inspiration for the compilation of ushûl fiqh theories. Even so, arRisâlah has not provided a theoretical formula regarding maslahah. Maslahah is still in the form of a spirit and a basic embryonic framework in the discussion of illat qiyâs.

Apart from that reality, arRisâlah became the opening of the gates of the theory of ushûl fîqh in general and maslahah in particular. After the ar-Risâlah, studies about maslahah began to appear. Qâdhi Abû Bakr al-Bâqillânî (d. $403 \mathrm{H}$ ) can be considered as the foundation for the theory of maslahah. Cited by al-Juwainî, introduced the initial formulation of the concept of maslahah with the terminology al-istidlâl, ${ }^{70}$

to reality through fiqh products at a practical level.

70 The term al-istidlâl which was introduced by al-Bâqillânî, was basically meant for the practice of istinbath law by using the scales of reason to find benefit for cases that did not have text information, which later became known as the term "almashlahah al-mursalah". Abû AlMa'ali Al-Juwainî, Al-Burhân fî Ushûl al-Fîqh, poin pembahasan Nomor. 1132, (Qatar, Fakultas Syarî"ah Universitas Qatar: 1399 H), 1115 
which ushûl fîqh theorists, including: further refined.

Abû al-Mâ'ali al-Juwainî was the first scholar who emphasized the urgency of understanding maqâshid asysyarî'ah in legal stipulation. An important contribution of alJuwainî is his formulation of maslahah levels based on urgency. In the discussion of 'illat, the principal (ashl) aims of Shari' are divided into three categories; adh-dharûriyât (primary), al-hâjiyât (secondary), and al-mukarrimât wa at-tahsiniyât (tertiary, complementary). ${ }^{71}$

This classification becomes the main basis for the study of maslahah and maqâshid syarîah afterwards. In order to sharpen the discussion of terms al-istidlâl al-Bâqillanî, al-Juwainî introduced the term al-istishlâh,72 which was later developed elaborative by his student, al-Ghazalî.

In the view of Abû Hâmid al-Ghazalî, the theory of maslahah has made significant progress and is beginning to

71 Abû Al-Ma'ali Al-Juwainî, Al-Burhân fî Ushîl, poin Nomor. 901-903, 923-924

72 Abû Al-Ma'ali Al-Juwainî, Al-Burhân fì Ushûl, poin Nomor. 1131,1114 find its concrete form. The term al-istishlâh which was introduced by al-Juwainî, is discussed as a separate conceptual theme. Maslahah has also been given a theoretical design and terminological definition framework.

Al-Ghazalî clarifies the formulation of al-Bâqillânî about al-istidlâl with the expression of the term maslahah explicitly, and breaks it down into three parts: 1) Maslahah which is legal based on the legitimacy of the testimony of the Shari'a; 2) Maslahah that is vanity based on the testimony of the Sharia; and 3) Maslahah for which there is no information from the Shari'a regarding its validity or impotence.73

Al-Istishlâh al-Ghazalî is meant for maslahah which has autonomous authority in its own essence, differentiated on three levels; adhdharûriyât, al-hâjiyât, and attahsiniyât wa at-tazyinât. Not only that, the concept of dharûriyât al-Juwainî was sharpened by the formulation of maqâshid asy-syarî'ah which was originally focused

73 Abû Hâmid al-Ghazalî, AlMustashfâ min 'Ilm., Jilid. 2, 378-481 
on maintaining the five fundamental maslahah (dharûriyât al-khamsah), namely religion, soul, reason, descent, and human property. ${ }^{74}$

Al-Ghazalî classifies maslahah based on personal implications, into three: 1) $\mathrm{Al}$ mashlahah al-'âmmah, which applies universally to all humans; 2) Al-mashlahah alaghlabiyah, which applies to the majority; and 3) Al-Mashlahah asy-syakhshiyah, which applies specifically to certain individuals. 75

Furthermore, Muhammad Musthafâ Syalabî offers several ideas about maslahah in his book Ta'lîl al-Ahkâm. Shalabî states that in certain contexts, changes in maslahah can affect changes in legal status (tabddul al-ahkâm bi tabddul al-mashlahah).

The idea of Shalabî maps out two categories of maslahah, namely: 1) Almashâlih ats-tsabitât (constant maslahah) which is immune to change, usually related to tawqîfî matters such as worship, hudûd, and

${ }^{74}$ Abû Hâmid al-Ghazalî, $A l$ Mustashfâ min 'Ilm., Jilid. 2, 481-482

${ }^{75}$ Abû Hâmid al-Ghazalî, $\mathrm{Al}$ Mustashfâ min 'Ilm, 210 others; 2) Al-mashâlih almutaghayyirât (maslahah temporal), which can change according to conditional reality, space, and time. This has to do with 'urf, empirical traditions, and patterns of interaction (muamalah) between humans. ${ }^{76}$

According to Abdul Karim Zidan, there are three maslahah classifications based on the legitimacy of the texts ${ }^{77}$ :

76 This concept is identical to the formula of Ibn al-Qayyim in his statement: "Al-ahkam consists of two types; (1). Laws whose status will not change by the influence of the times, places, and the ijtihâd of the scholars, such as compulsory and haram cases, hudûd sanctions that have been established by the Sharia for criminal practices, etc. All legal provisions of this type cannot be changed and diijtihadi to turn them away from the status stipulated by sharia; and (2). Laws whose status can change according to the demands of maslahah consequences due to changing times, places and conditions, such as sanctions for ta'zir law based on the type of crime, actually the provisions of the syar 'i for them vary in level because they consider the demands of maslahah consequences. " Ibn al-Qayyim alJauziyah, Ighâtsatu al-Luhfân fî Mashâyidi asy-Syaithân," Jilid. 1, (Makkah, Dâr 'Âlam al-Fawâ'id: $1433 \mathrm{H}), 570-571$.

77 Abdul Karim Zidan, "AlWajiz fii Ushul Figh". Cet VII. 
first, al-maslahah almu'tabarah; second, almaslahah al-mulgah; and third, al-maslahah al-mursalah. Al-maslahah al-mu' tabarah $^{78}$ is benefit that has the support of syara ', both in type and form. Al-maslahah al-mulghah ${ }^{79}$ is benefit that is rejected by syara 'because it is against the provisions of syara'. Almaslahah al-mursalah ${ }^{80}$ is a benefit whose existence is not supported by syara 'and is not canceled (rejected) by syara' through detailed arguments.

\section{Marketing Mix in Maslahah Perspective}

The marketing mix dominates the marketing concept of Islamic education ${ }^{81}$.

(Baghdad: Muassasah Qurthubah, 1976), 236

78 Abdul Karim Zidan, "AlWajiz, 236

79 Abdul Karim Zidan, "AlWajiz, 237

80 Abdul Karim Zidan, "AlWajiz, 237

81 The marketing mix is one of the marketing strategies to convey information widely, introduce goods and services, stimulate consumers to give and even create personal preferences for the image of a product. See, Christian A D Selang, “Bauran Pemasaran (Marketing Mix) Pengaruhnya Terhadap Loyalitas Konsumen Pada Fresh Mart Bahu
Marketing mix is a customeroriented marketing concept that uses controllable variables and marketers use to achieve marketing goals. This marketing mix is analyzed according to the institution's conditions and capabilities,, 82

Mall Manado," EMBA 1, no. 3 (2013): 71-80.

82 Johari, Jamil Hamali, and Firdaus Abdullah, "Islamic Marketing Mix: The Critical Factors," INTERNATIONAL CONFERENCE ON BUSINESS AND ECONOMIC RESEARCH $(4 T H$ ICBER 2013) PROCEEDING, no. March (2013): 1142-59; Syahrial Labaso, "Penerapan Marketing Mix Sebagai Strategi Pemasaran Jasa Pendidikan Di MAN 1 Yogyakarta," Manageria; Jurnal Manajemen Pendidikan Islam 3, no. November (2018): 289-311; Puspo Dewi Dirgantari, "Peranan Bauran Pemasaran Jasa Pendidikan Terhadap Upaya Meningkatkan Ekuitas Merek Berbasis Pelangga Perguruan Tinggi," Strategic; Jurnal Pendidikan Manajemen Bisnis 11, no. 20 (2016): 22-31; Sutama and Sri Walji Hasthanti, "Bauran Marketing Jasa Pendidikan Sekolah Dasar Muhammadiyah," Managemen Pendidikan 13, no. 2 (2018): 190-203; Dedek K Gultom, Paham Ginting, and Beby K F Sembiring, "Pengaruh Bauran Pemasaran Jasa Dan Kualitas Pelayanan Terhadap Kepuasan Mahasiswa Pregram Studi Manajemen Fakultas Ekonomi Universitas Muhammadiyah Sumatera Utara," MANAJEMEN \& BISNIS 14, no. 01 (2014): 21-33; 
resulting in different concepts from one institution to another. Islamic education marketing mix, among others:

1. Product; product mix in education includes reputation, prospects, variety of options ${ }^{83}$, and excellent programs. In the marketing of Islamic education, products, both goods and services, must pay attention to lawfulness ${ }^{84}$ (allowed by sharia), halal ${ }^{85}$, and no

Tasman H Taher, "Pengaruh Bauran Pemasaran Terhadap Kepuasan Layanan Jasa Pendidikan Di Sekolah Tinggi Ilmu Ekonomi ( Stie ) Palangkaraya," JSM (Jurnal Sains Manajemen) II, no. September (2013): 1-11.

83 Buchari Alma, Manajemen Corporate, 157

84 Legal according to law means not being close minded, not causing trouble to the public, and there are no elements that are prohibited by sharia. Samir Abuznaid, "Islamic Marketing: Addressing the Muslim Market," An - Najah Univ. J. Res. (Humanities) 26, no. 6 (2012): 1473-1503; Selim Ahmed and Habibur Rahman, "The Effect of Marketing Mix on Consumer Satisfaction: A Literature Review from Islamic Perspective," Turkish Journal of Islamic Economics 2, no. 1 (2015): 17-30.

85 According to Alserhan, three halal categories in marketing are food, lifestyle, and service. Baker things that are prohibited in providing goods and services offered to consumers. ${ }^{86}$ The halal category here includes the halalness of products and services from the beginning to the end of the production process and the halalness in the process of delivery. ${ }^{87}$ These criteria are enforced in order to provide benefits for education customers.

This product mix in the category of maslahah urgency is maslahah dharuriyyat or primary, because the product is a basic need desired by educational customers. Maslahah category in terms

Ahmad Alserhan, "On Islamic Branding: Brands as Good Deeds," Journal of Islamic Marketing 1, no. 2 (2010): 101-106, https://doi.org/10.1108/175908310 11055842.; According to Aloem and Haque, halal products in Islamic marketing are described in AlQur'an 2: 168

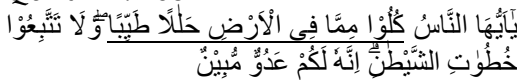

"O people! Eat of the clean and good (food) that is on earth, and do not follow in the steps of Satan. Really, the devil is a real enemy to you "

86 Fathoni, "Konsep Pemasaran Dalam Perspektif Hukum Islam."

87 Arham, "Islamic Perspectives on Marketing." 159. 
of quantity, product mix includes maslahah al'ammah because the product aims to provide benefit to all customers. This product mix is included in the maslahah mutaghayyarah category because the products in the form of educational institutions' services are temporal and dynamic in nature following the wishes and needs of customers according to their era. Furthermore, this product mix is included in the maslahah mu'tabarah category, because in the product mix there is a halal category both in goods and services provided to customers as explained in al-Qur'an 2: 168.

In essence, the product mix application in marketing Islamic education must pay attention to the maslahah level for its customers. This is because products in marketing are desired by customers that will provide value to them and attract interest and increase customer trust.

2. Price; prices in the education sector include tuition fees, re-registration, committee fees, and others related to costs during education. ${ }^{8}$ The price mix in marketing Islamic education must pay attention to the principle of being equally willing89, meaning that the price determination must be in accordance with a logical and fair profit. Healthy price competition 90 between competitors should also be a concern for education managers, which means in determining the price of goods and services of good quality and appropriate prices. The determination of the price mix must be in

88 Abdillah Mundir, "Strategi Pemasaran Jasa Pendidikan Madrasah," Malia 7, no. 1 (2016): 2740 .

89 In Aloem and Haque's research, it is known as mutual consent, namely mutual consent, this means that the exchange must be operated with the free will of the buyer and seller and free from pressure, fraud, and even fraud. See, Alom and Haque, "Marketing: An Islamic Perspective."; $H$. Muhammad Birusman Nuryadin, "Harga Dalam Perspektif Islam," Mazahib 4, no. 1 (2007): 86-99.; This is as in the Qur'an 4: 29

90 Prohibition of manipulating the price required by the market. See, Abuznaid, "Islamic Marketing: Addressing the Muslim Market." 
accordance with the customer's concerns.

The price mix is urgently maslahah a dharuriyyat or primary maslahah, because price is the main issue that one wants to know and is a determining factor in choosing educational institutions for customers. If the price paid does not match the quality of the services provided, the customer will feel disappointed and will no longer trust the service provider institution. Maslahah category in terms of quantity or coverage, this mix includes maslahah al'ammah because price aims to benefit all customers and not for the majority or individual customers. This mix is included in the category of maslahah mutaghayyarah because the educational institution's price is temporal and dynamic, following the wishes, economic capabilities, and needs of customers. Meanwhile, from the aspect of legal legitimacy, this price mix is included in the category of maslahah mu'tabarah because in determining the price applied must be willing to be equally willing or logical and fair to customers as in Al-Qur'an 4: 29.

The classification of maslahah in the price mix is very important for Islamic education institutions to pay attention to in implementing Islamic education marketing. This is because this mix is an element that is very vulnerable to attention by customers in determining their trust in an educational institution. If the price set by Islamic education institutions does not match the quality of the services provided and is deemed unfair, then customers will no longer trust the institution concerned. Conversely, suppose the price set by an Islamic education institution is in accordance with the quality of its services. In that case, the customer will be more interested and increase their trust in the educational institution.

3. Place; location in education marketing is a place where the marketing of services is carried out, namely schools 
and the surrounding environment. ${ }^{91}$

A

convenient, strategic ${ }^{92}$, clean and safe location is what attracts customers to educational institutions. ${ }^{93}$ Apart from physical locations, these locations can also be reached virtually via the internet. This is in accordance with the principles of marketing Islamic education, namely that it does not make it difficult for customers to access service locations/places and facilitate their needs. ${ }^{94}$ In line with this, Islam states that the common good (maslahah al-'ammah) is more important than personal interests. In the legal system category, this mix is included in the maslahah mursalah category. In determining this mix, Islamic marketers must pay attention to aspects of convenience and ease of location access to not complicate customers.

4. Promotion; promotion in the context of education can be done by advertising 95 (advertising) ${ }^{96} \quad$ through print and electronic media,

https://doi.org/10.1108/175908310 11055851.3.

95 Advertising in Islamic marketing includes the type and purpose of advertising, advertising function, advertising levels, advertising references, advertising ideology, advertising language, ad image enhancers, the impact of advertising on society. See, Amrul Mutaqin, "Konsep Periklanan Dalam Ekonomi Islam," Jurnal Cahaya Aktiva 03, no. 01 (2013): 1-10. 96 Advertising is analyzed in the light of Quranic injunctions on truthfulness, spending behavior, publishing ethics, and human dignity. Muhammad Anwar and Mohammad Saeed, "Promotional Tools of Marketing: An Islamic Perspective," Intellectual Discourse 4, no. 1 (1996): 15-30. 
sales promotion (exhibition, invitation), direct selling, and conducting public relations activities in the form of community service programs. ${ }^{97}$ This promotion mix must pay attention to the content used in the promotion, the media used, the location or position of the promotion, and the distinction of educational institutions so that it becomes a special attraction for education customers. The content used must be in accordance with the quality of the institution, so as not to cause customer disappointment and there is no element of fraud.98 Because in Islam, customer maslahah is very important and a major concern in all marketing activities.

97 Kalthom Abdullah and Mohd Ismail Ahmad, "Compliance to Islamic Marketing Practices among Businesses in Malaysia," Journal of Islamic Marketing 1, no. 3 (2010):

286-97, https://doi.org/10.1108/175908310 11082446; Khasanah, "Pemasaran Jasa Pendidikan Sebagai Strategi Peningkatan Mutu Di SD Alam Baturraden"; Mundir, "Strategi Pemasaran Jasa Pendidikan Madrasah."

$$
98 \text { Arham, "Islamic }
$$

Perspectives on Marketing."
Maslahah urgently in this promotion mix is included in the maslahah dharuriyyat category because educational institutions need to carry out promotions with media that can be done and used by educational institutions in this competitive era. In terms of quantity or coverage, this mix includes maslahah al-'ammah because the promotion aims to convey information about the institution to educational customers for the benefit of all customers and not for the majority or individual customers. This mix is included in the category of maslahah mutaghayyarah because the promotions carried out by Islamic education institutions are temporal and dynamic in tcustomers' wishes and needsers. Furthermore, based on legal legality, this mix is included in the category maslahah mu'tabarah because the determination of this mix must be honest in accordance with what is owned by the institution, as the attitude of the Prophet in conveying the good and 
bad conditions of his merchandise.

Customer issues are something that Islamic education institutions need to pay attention to in determining which promotions will be carried out. If an Islamic education institution is not correct in determining its institution's promotion, many educational customers will turn away from the educational institution. As a result, these Islamic educational institutions' existence is not strong enough to be hit by the competition from its competitors.

5. People; People in the marketing of educational services can be interpreted as human resources (employees) who are directly involved, such as educators (teachers) and education personnel such as administrative staff and other employees. The selection of human resources is very urgent because it can have an impact on the success of the goals of education. So that the processing of human resources should be carried out professionally based on their qualifications and competencies. Islam has explained that a marketer must be polite, gentle, honest, and smile friendly. In addition, we must be able to think rationally and care about customers' feelings and behavior to feel comfortable.

Maslahah urgently in this mix is included in the maslahah category dharuriyyat educational institutions need to pay attention to their resources properly in order to provide maximum service. In terms of quantity, this mix is included in maslahah al-'ammah because human resources in educational institutions need to be considered without exception to achieve educational goals. This mix is also included in the category of maslahah mutaghayyarah because the nature of human resources in educational institutions is temporary and dynamic following the needs and conditions of today's society. Furthermore, based on legal legitimacy, this mix is in the category of maslahah mu'tabarah because if the human 
resources in educational institutions are not good according to Islamic law, the educational institution will lose the trust and interest of its customers.

6. Physical Evidence; There are two categories in this mix in the world of education: school buildings or buildings, classrooms, library buildings, sports fields, rooms, and others. Second, evidence supporting the process of delivering education has a very important role in the process of educational services such as report cards, student records, and others.

This mixture is urgently maslahah a dharuriyyat or primary maslahah, because educational institutions need good physical evidence and are following the Shari'a so that customers feel attracted and increase their trust in the institution. In terms of quantity, this mix is in the category of maslahah al-'ammah, because of this good and comfortable mix, all elements of educational institutions both internal and external to the institution will further increase their trust in the institution. In terms of changes in shape, this mix is included in the category of maslahah mutaghayyarah because this mix's nature is dynamic according to the needs of the institution and the surrounding community. Furthermore, in terms of the legitimacy of the texts, this mix is included in the category maslahah mu'tabarah because this mix is adjusted to existing laws, for example clean, comfortable, and others.

7. Process; This mix in educational services is an educational process that supports the implementation of teaching and learning activities to realize educational goals. .9 Process elements include the procedures, mechanisms and flow of activities through which

\footnotetext{
99 Sarifudin dan Rehendra Maya, "Implementasi Manajemen Pemasaran Jasa Pendidikan Dalam Meningkatkan Kepuasan Pelanggan di Madrasah Aliyah Terpadu (Mat) Darul Fallah Bogor," Islamic Management: Jurnal Manajemen Pendidikan Islam, Vol. 02, No. 02, Juli 2019, 135-154.
} 
services are provided. So that this mix is a series of all marketing activities carried out.

This mix is urgently included in the maslahah dharuriyyat category because this mix is a mix that customers always want to know so that they are increasingly convinced and trusting in the institution. In terms of quantity, this mix is included in the category maslahah

al-'ammah because all processes that occur in educational institutions are carried out to increase customer satisfaction both physically and mentally. In addition, this mix is also included in the category maslahah mu'tabarah in terms of the legitimacy of texts. This is because the implementation of this mix must be in accordance with the text. If it is not in accordance with the authentic texts, then customer trust in the institution will decrease.

The marketing mix applied by educational institutions must be adjusted to the customers' maslahah or utility level, both internal and external. If not, then education customers will not feel that they benefit both physically (zahiriyah) and nonphysically (bathiniyah) ${ }^{100}$ as a form of obedience to God to obtain glory in an eternal life, namely the hereafter. The better the application of the marketing mix in educational institutions, the higher the level of maslahah or customer utility. Conversely, if the application of the marketing mix is not good and is not in accordance with customer wishes, then the level of maslahah or customer utility will decrease or decrease.

\section{Conclusion}

Based on the explanation above, it can be concluded that education customers' issue is the main objective of all Islamic education marketing activities,

100 These two dimensions are related to each other, but on the other hand, they do not go hand in hand or attract each other. This is because the orientation of the fulfillment is like a different magnetic side. Ainun Barakah, “Utilitas dalam Perilaku Konsumen Perspektif Keislaman", Jurnal CENDEKIA; Jurnal Studi Keislaman 4, no. 2 (2018): 236 
including the marketing mix applied by educational institutions. The maslahah perspective education marketing mix is urgently included in the maslahah dzurriyyat / primary category because the marketing mix is a basic requirement of an educational institution in marketing. In terms of quantity or scope, the marketing mix includes maslahah al-'Ammah because the aim is to convey information about the institution to educational customers for the benefit of all customers and not for the majority or individual customers. The marketing mix is included in the maslahah mutaghayyarah category because it has a temporal and dynamic nature following customer wants and needs. Finally, the Islamic education marketing mix is included in the category maslahah mu'tabarah as long as the marketing mix applied does not conflict with syar'i arguments.

This Islamic education marketing study still has many shortcomings because its scope only includes the customer issue-level and has not yet reached the realm of customer ethics. The author recommends the following authors to conduct a study on the marketing of Islamic education on the ethical aspects of customer education based on Islamic teachings and the concept of marketing Islamic education on a broader aspect of ethical aspects.

\section{Bibliography}

Abdullah, Kalthom, and Mohd Ismail Ahmad. “Compliance to Islamic Marketing Practices among Businesses in Malaysia." Journal of Islamic Marketing 1, no. 3 (2010): 286-97. https://doi.org/10.1108 /17590831011082446.

Abuznaid, Samir. "Islamic Marketing: Addressing the Muslim Market." An - Najah Univ. J. Res. (Humanities) 26, no. 6 (2012): 1473-1503.

Adinugraha, Hendri

Hermawan. "Pemasaran Syariah Di Lembaga Keuangan Mikro Islam: Konsep Dan Implementasi Di Puskopsyah DIY." Perisai: Islamic Banking and Finance Journal 1, no. 3 (2017): 180. 
https://doi.org/10.2107

0/perisai.v1i3.969.

Adnan, Ahmad Azrin.

"Theoretical Framework

for Islamic Marketing:

Do We Need a New

Paradigm ?"

International Journal of

Business and Social

Science 4, no. 7 (2013): 157-65.

Afifi, Subhan, and Edy Susilo.

"Pengembangan

Komunikasi Pemasaran

Sekolah."

Ilmu

Komunikasi 13, no. 3 (2014): 277-86.

Ahmadova, Emiliya. "Islamic

Marketing: The New

Rules That Transform

The Way of Conducting

Business." Journal of

Suleyman Demirel

University Institute of

Social Sciences 1, no. 2 (2016).

https://doi.org/10.1108

/17590831011055851.3.

Ahmed, Selim, and Habibur

Rahman. "The Effect of

Marketing Mix on

Consumer Satisfaction:

A Literature Review

from Islamic

Perspective." Turkish

Journal of Islamic

Economics 2, no. 1 (2015): 17-30.

Alom, Mahabub, and Shariful
Haque. "Marketing: An Islamic Perspective Alom \& Haque." World Journal of Social Sciences 1, no. 3 (2011): 71-81.

Alserhan, Baker Ahmad. "On Islamic Branding:

Brands as Good Deeds." Journal of Islamic Marketing 1, no. 2 (2010): 101-6.

https:// doi.org/10.1108

/17590831011055842.

Ambarsari, Dessy. "Strategi

Pemasaran Untuk

Perguruan Tinggi Di Indonesia." EKOMAKS; Jurnal Ilmu Ekonomi, Manajemen, Dan

Akutansi 6, no. 1 (2017).

Andharini, Sri Nastiti, Dewi

Nurjannah, and Eka

Kadharpa. "Komunikasi

Pemasaran Jasa Pada

Pendidikan Tinggi Di

Malang." Seminar

Nasional Dan Gelar

Produk, 2016, 585-91.

Anwar, Muhammad, and

Mohammad Saeed.

"Promotional Tools of

Marketing: An Islamic

Perspective." Intellectual

Discourse 4, no. 1 (1996): 15-30.

Arham, Muhammad. "Islamic

Perspectives on

Marketing." Journal of Islamic Marketing 1, no. 
2 (2011): 149-64. https:// doi.org/10.1108 /17590831011055888.

Arisandy, Yosy.

"Womanology

Perspektif Islam (Strategi

Pemasaran

Pada

Perempuan)." Jurnal Hawa 1, no. 1 (2019): 1934.

Aziz, Muhammad. Branding Of Halal Products In Indonesia: Contestation Between Religious, Identity And Commodity Interests. Akademika: Jurnal Pemikiran Islam, [S.1.], v. 25, n. 1, p. 139-164, aug. 2020. ISSN 2356-2420. Available at: <http://ejournal.metrouniv.ac.id/ index.php/akademika/a rticle/view/2102>. Date accessed: 14 oct. 2020. doi:

https://doi.org/10.3233

2/akademika.v25i1.2102.

Aziz, Muhammad, Ahmad Rofiq, and Abdul Ghofur. "Regulasi Penyelenggaraan Jaminan Produk Halal Di Indonesia Perspektif Statute Approach". ISLAMICA: Jurnal Studi Keislaman 14, no. 1 (September 1, 2019): 151170. Accessed October
14 2020. http://islamica.uinsby.a c.id/index.php/islamica /article/view/577.

Barakah, Ainun. "Utilitas dalam

Perilaku

Konsumen Perspektif

Nilai

Keislaman."CENDEKIA;

Jurnal Studi Keislaman 4, no. 2 (2018): 236

Birusman Nuryadin, $H$. Muhammad. "Harga Dalam Perspektif Islam." Mazahib 4, no. 1 (2007): 86-99.

Borden, Neil H. "The Concept of Marketing Mix." Journal of Advertising (1984): 7-12.

Consoli, Domenico. "A New

Concept of Marketing: The Emotional Marketing." BRAND. Broad Research in Accounting, Negotiation, and Distribution 1, no. 1 (2010): 1-8.

Dewi Dirgantari, Puspo.

"Peranan Bauran

Pemasaran Jasa

Pendidikan Terhadap Upaya Meningkatkan Ekuitas Merek Berbasis Pelangga Perguruan Tinggi." Strategic; Jurnal Pendidikan Manajemen Bisnis 11, no. 20 (2016): 22-31. 
Disuma, Anggara. "Syariah

Marketing: Strategi

Memenangkan

Persaingan Global," 2015, 1-13.

Elytasari, Suvidian. "Strategi

Pemasaran Jasa

Pendidikan

Meningkatkan

Kepercayaan

(Trust)

Stalholders Di TK Amal Insani Depok

Yogyakarta." Jurnal WARNA 1, no. 1 (2017): 117-54.

Faizin, Imam. "Strategi

Pemasaran Jasa

Pendidikan Dalam

Meningkatkan Nilai Jual

Madrasah." Madaniyah

7, no. 2 (2017): 261-83.

Fakhrurozi.

Pemasaran

"Strategi

Pendidikan Jasa

Meningkatkan

Dalam

Pendidikan

Citra

Jurnal Pemikiran, Riset

Dan Pengembangan

Pendidikan Islam 7, no. 2 (2012): 207-32.

Fathoni, Muhammad Anwar.

“Konsep Pemasaran

Dalam Perspektif

Hukum Islam."

Jurisdictie: Jurnal

Hukum Dan Syariah 9, no. 1 (2018): 128-46.

Fatmawati, Hany, and Puwidi

Sumaryanto. "Analisis
Strategi Pemasaran SMK

Darul Ma'arif Kota

Administrasi Jakarta

Utara." Bina Manfaat

Ilmu; Jurnal Pendidikan

02, no. 05 (2019): 393410.

Fauzi, Yayan. "Manajemen Pemasaran Perspektif Maqasid Syariah." Jurnal Ilmiah Ekonomi Islam 1, no. 03 (2015). https://doi.org/10.2904 0/jiei.v1i03.51.

Gultom, Dedek K, Paham Ginting, and Beby K F Sembiring. "Pengaruh Bauran Pemasaran Jasa Dan Kualitas Pelayanan Terhadap Kepuasan Mahasiswa Pregram Studi Manajemen Fakultas Ekonomi Universitas

Muhammadiyah

Sumatera Utara."

MANAJEMEN \& BISNIS 14, no. 01 (2014): 21-33.

Hasan, Abul et. al. "Islamic Marketing Ethics and Its Impact on Customer Satisfaction in the Islamic Banking Industry." JKAU: Islamic Econ vol. 21, no. 1 (2008): 27-46.

Jafari, Aliakbar. "Islamic Marketing: Insights from a Critical Perspective." 
Journal of Islamic

Marketing 3, no. 1 (2013):

22-34.

https://doi.org/10.1108

/17590831211206563.

Johari, Jamil Hamali, and Firdaus Abdullah.

"Islamic Marketing Mix:

The Critical Factors."

INTERNATIONAL

CONFERENCE ON

BUSINESS

AND

ECONOMIC

RESEARCH (4TH ICBER

2013) PROCEEDING, no.

March (2013): 1142-59.

Kazoleas, Dean, Yungwook

Kim, and Mary Anne

Moffitt. "Institutional

Image: A Case Study."

Corporate

Communications: An

International Journal 6, no. 4 (2001): 205-16.

https://doi.org/10.1108

/EUM0000000006148.

Khasanah,

Afidatun.

"Pemasaran

Jasa

Pendidikan Sebagai

Strategi Peningkatan

Mutu Di SD Alam

Baturraden." El-Tarbawi;

Jurnal Pendidikan Islam

VIII, no. 2 (2015): 161-76.

http://dx.doi.org/10.20

885/tarbawi.vol8.iss2.art

4.

Labaso, Syahrial. "Penerapan

Marketing Mix Sebagai
Strategi Pemasaran Jasa Pendidikan Di MAN 1 Yogyakarta." Manageria; Jurnal Manajemen Pendidikan Islam 3, no. November (2018): 289311.

Low, S. P. \& Kok, H. M. "Formulating A Strategic Marketing Mix for Quantity Surveyors." Marketing Intelligence \& Planning 15, NO. 6 (1997), 273-280.

MaGrath, A. J. "When Marketing Services, 4Ps Are Not Enough."

Business Horizons 29, no. 3 (1986): 45-50.

Manea, Natalia, and Mihaela Purcaru. "The Evolution of Educational

Marketing."

International Scientific Conference on Economic Sciences and Business Administration, no. 4 (2017): 37-45.

Maya, Sarifudin dan

Rehendra.

"Implementasi

Manajemen Pemasaran Jasa Pendidikan Dalam Meningkatkan Kepuasan Pelanggan di Madrasah Aliyah Terpadu (MAT) Darul Fallah Bogor." Islamic Management: Jurnal Manajemen 
Pendidikan Islam Vol. 02, No. 02 (2019): 135154.

Möller, K."The Marketing Mix Revisited: Towards the 21st Century Marketing by E. Constantinides." Journal of

Marketing

Management 22, no. 3 (2006): 439-450.

Mundir, Abdillah. "Strategi Pemasaran Jasa Pendidikan Madrasah." Malia 7, no. 1 (2016): 2740.

Mutaqin, Amrul. "Konsep Periklanan Dalam

Ekonomi Islam." Jurnal Cahaya Aktiva 03, no. 01 (2013): 1-10.

Nurcholifah, Ita. "Strategi

Marketing Mix Dalam Perspektif Syariah." Jurnal Khatulistiwa Journal Of Islamic Studies 4, no. 1 (2014): 73-86.

Purwanto, Nurtanio Agus. "Strategi Bersaing Dalam Bisnis Pendidikan."

Manajemen Pendidikan VII, no. 01 (2011): 9-16.

Qomariah, Nurul. "Pengaruh

Kualitas Layanan Dan

Citra Institusi Terhadap Kepuasan Dan Loyalitas Pelanggan (Studi Pada Universitas
Muhammadiyah Di Jawa Timur)," 2012.

R. E., Goldsmith. "The Personalised

Marketplace: Beyond the 4Ps." Marketing Intelligence and Planning 17, no. 4 (1999): 178-185.

Riaz, Muhammad. "Islamic Marketing Ethics and The Marketing Pravtices of Islamic Banks." ISRA International Journal of Islamic Finance 8, no. 2 (2016): 27-49.

Sahla, Hilmiatus. "Konsep

Pemasaran

Dalam

Perspektif Ekonomi Islam" 5 (2019): 57-61.

Sandikci,

Ozlem.

"Researching Islamic Marketing: Past and Future Perspectives." Journal of Islamic Marketing 2, no. 3 (2011): 246-58.

https://doi.org/10.1108 /17590831111164778.

Selang, Christian A D. "Bauran Pemasaran (Marketing Mix) Pengaruhnya Terhadap Loyalitas Konsumen Pada Fresh Mart Bahu Mall Manado." EMBA 1, no. 3 (2013): 71-80.

Sholikah, S., Syukur, F., Junaedi, M., \& Aziz, M. 
(2020).

Pendidikan

dalam

Al-Qur'an

Perspektif Abdurrahman

Saleh Abdullah dalam

Tinjauan

Filsafat

Pendidikan Islam. Al

Hikmah: Jurnal Studi

Keislaman, 10(1), 117127. Retrieved from http:// ejournal.kopertai s4.or.id/pantura/index. php/alhikmah/article/v iew/3494.

Sholikah, S. (2019). Branding Institusi Perguruan

Tinggi Keagamaan Islam Swasta Di Kawasan Pesisir (Studi Multi Situs Di STITMA Tuban Dan IAI Tabah Kranji Paciran Lamongan). Al Hikmah: Jurnal Studi Keislaman, $8(2)$, 184-196. https://doi.org/10.3683 5/hjsk.v8i2.3383

Susanti, Martien Herna. “Model Pendidikan

Kewirausahaan Di

Perguruan Tinggi Dalam

Menumbuhkan

Entrepeneur Muda

Kreatif Dan Inovatif Di Kota Semarang."

FORUM ILMU SOSIAL

41, no. 1 (2014): 41-53.

Sutama, and Sri Walji

Hasthanti.

Marketing

Pendidikan
"Bauran Jasa
Dasar Muhammadiyah." Managemen Pendidikan 13, no. 2 (2018): 190-203.

Taher, Tasman H. "Pengaruh

Bauran Pemasaran

Terhadap Kepuasan

Layanan Jasa Pendidikan

Di Sekolah Tinggi Ilmu Ekonomi ( Stie ) Palangkaraya." JSM (Jurnal Sains Manajemen) II, no. September (2013): 1-11.

Tahir, A.G, S.A.A Rizvi, and Farooq KhAhmad. "Keys of Educational Marketing." Journal of Applied Environmental and Biological Sciences 7, no. 1 (2017): 180-87.

Tresnati, Ratih, and Nina

Maharani. "Kajian

Tentang Strategi

Pemasaran Syariah

Dalam Penguatan Daya Saing UKM Menghadapi AEC 2015 Di Indonesia." Proceedings SNEB 2014, 2015, 1-11.

“Undang-Undang No 20 Tahun 2003," 2003.

Vignali, C. \& Davies, B. J. "The Marketing Mix Redefined and Mapped Introducing the MIXMAP Model." Management Decision 32, no. 8 (1994): 11-16.

Wahyudi, 
"Manajemen Pemasaran Pendidikan." Kariman 05, no. 01 (2017): 65-82.

Widiasih, Wiwin. "Studi

Komparasi Implementasi

Manajemen Proses Bisnis

Pada Lembaga Profit

Dan Nonprofit." Seminar

Nasional Terpadu

Keilmuan Teknik

Industri, 2015, 1-6.

Wilson, Jonathan A.J. "The

New Wave of

Transformational Islamic

Marketing Reflections and Definitions." Journal of Islamic Marketing 3, no. 1 (2012): 5-11.

Wilson, Jonathan. "Looking at Islamic marketing, branding and Muslim consumer behaviour beyond the 7P's." Journal of Islamic Marketing, Vol. 3, No. 3 (2012), 212-216.

Book's:

'Asyûr, Muhammad Thahir

Ibnu. Maqâshid asySyarî'ah al-Islâmiyah.

Yordania: Dâr an-

Nafâecis. 2001

Abdissalâm, Izzuddîn bin. Al-

Qawâ'id al-Kubrâ;

Qawâ'id al-Ahkâm fî

Mashâlih al-Anam.

Damaskus: Dâr al-

Qalam: 2000
Al-Ghazalî, Abû Hâmid. AlMustashfâ min 'Ilm alUshûl, Jilid. 2. Beirut: Dâr al- Kutub alIlmiyah. 2010

Al-Ghazalî, Abu Hamid. Syifâ' al-Ghalîl fî Bayâni asy-Syabahi wa alMukhayali wa Masâlik at-Ta'lîl. Baghdad: Mathba"ah Al-Irsyâd. 1971

Al-Jauziyah, Ibn al-Qayyim. Ighâtsatu al-Luhfân fî Mashâyidi asy-Syaithân. Jilid 1. Makkah: Dâr 'Âlam al-Fawâ' id. 1433H Al-Juwainî, Abû Al-Ma'ali. Al-Burhân fî Ushûl alFîqh. Qatar: Fakultas Syarîeah Universitas Qatar. 1399H

Al-Khin, Musthafâ Sa'îd. Abhâts Haula Ushûl alFîqh: Târîkhuhu wa Tathawwuruh.

Damaskus: Dâr al-Kalâm ath-Thayyib. 2000

Alma, Buchari. Manajemen Corporate dan Strategi Pemasaran Jasa Pendidikan; Fokus pada Mutu dan Layanan Prima. Bandung: Alfabeta. 2009

Alserhan, Baker Ahmad. The Principles of Islamic Marketing. England: Gower Publishing 
Limited, 2011

Al-Yûbi, Muhammad Mas'ûd.

Maqâshid asy-Syarî́ah al-Islâmiyah wa

'Alâqatuha bi al-Adillati asy-Syar'îyah. Riyâdh:

Dâr al-Hijrah. 1998

Ar-Raysunî,

Ahmad.

Nazhariyât

al-

Maqâshid,,inda al-Imâm asy-Syâthibî. Amerika:

al-Ma'had al-Ma'âli li al-

Fikri al-Islâmî. 1995

Ar-Râzî, Fakhruddîn. Al-

Mahshûl fî Ilmi al-Ushûl.

Jilid. $5 . \quad$ Beirut:

Muassasah ar-Risâlah. tt

Assauri, Sofjan. Manajemen

Pemasaran. Jakarta: Raja

Grafindo. 2007

Asy-Syâfi'î, Muhammad

Idris. Ar-Risâlah, Jilid. 3.

Beirut: Dâr al-Kutub al„Ilmiyah. Tt

Asy-Syaukânî, Muhammad.

Irsyâd al-Fuhûl ilâ

Tahqîq al-Haq min Ilmi

al- Ushûl. Riyâdh: Dâr

al-Fadhîlah. 2006

Ath-Thufi, Najmuddin. Syarh al-Arba"in an-

Nawawiyah. Kairo. Dâr al-Bashâ'ir. Tt

Az-Zarqâ', Musthafâ Ahmad. Al-Madkhal al-Fîqhî al"Âm. Damaskus: Dâr alQalam. 1998

Bay, Hâtim. Al-Ushûl alIjtihâdiyah al-lati Yubna 'alaihâ al-Madzhab alMâlikî. Kuwait: al-Wâ'i al-Islâmî. 2011

Bogdan, Robert C, and Sari Knopp Biklen.

Qualitative Research for Education An

Introduction to Theory and Methods. 5th ed. USA: Pearson Education, Inc, 2006.

David Wijaya, Pemasaran Jasa Pendidikan “Mengapa Sekolah memerlukan

Marketing", (Jakarta:

Salemba Empat, 2012

French, Herek dan Saward, Heather. The Dictionary of Marketing, (London: Pans Book, 1982

Hasan, Husain Hâmid. Nazhariyat alMashlahah fî al-Fîqh alIslâmî. Kairo: Maktabah al-Mutanabbî, 1981

Kartajaya, Hermawan dan Sula, Muhammad Syakir. Syari'ah Marketing, (Jakarta: PT Mizan Pustaka), Cet. Ke 4, 2008

Khaldûn, Ibnu. Muqaddimah:

Târikh Ibnu Khaldûn. Jilid. 1. Beirut: Dâr AlFikr. 2001

Khallâf, Abdul Wahab. Mashadir at-Tasyrî́ fî ma La Nashsha Fîhi. Tkt: 
Dâr al-Maktabî. 1999

Kotler, Philip, and Amstrong,

Gary. Principles of

Marketing. 12th ed. USA:

Pearson Prentice Hall, 2008.

Kotler, Philip, and Keller,

Kevin Lane. Marketing

Management. 15th ed.

Edinburgh: Pearson

Education Limited, 2016.

Kotler, Philip dan Amstrong,

Gary. Principle of

Marketing 7e, alih

bahasa Alexander

Sindoro, (Jakarta:

Prenhallindo, 1997

Lazer, W. \& Kelly, E. K.

Managerial Marketing:

Perspectives and

Viewpoints. IL: Richard

D. Irwin. 1962.

Manzhûr, Ibnu. Lisân al'Arab. Kairo: Dâr AlMa'arif: tt

McCarthy, E. J. Basic

Marketing. IL: Richard

D. Irwin. 1964.

Muflih, Muhammad. Perilaku

Konsumen dalam

Perspektif Ilmu Ekonomi

Islam". Jakarta: PT. Raja

Grafindo Persada. 2006

Musthafâ Said al-Khin,

Dirasat at-Târîkhiyah li

al-Fîqh wa Ushûlih,

(Damaskus, asy-Syirkah al-Muttahidah li atTawzî́: 1984), 201-219
Nata, Abuddin. Kapita Selekta Pendidikan Islam. Bandung: Angkasa. 2003

Nur Rianto Al Arif, DasarDasar Pemasaran Bank Syariah, (Bandung: Alfabeta, 2010

Qudâmah, Ibnu. Raudhatu an-Nazhir wa Junnatu al-Munazhir. Riyad: tp. $1424 \mathrm{H}$

Sa'îd, Musthafâ. Abhâts Haula Ushûl al-Fîqh: Târîkhuhu wa

Tathawwuruh.

Damaskus: Dâr al-Kalâm ath-Thayyib. 2000

Salim, Peter dan Salim, Yenny. Kamus Bahasa Indonesia Kontemporer. Jakarta: Modern English Press. 2002

Syalabî, Muhammad Musthafâ. Ta'lîl alAhkâm. Kairo: Mathba"eh al-Azhar. 1947

Syarifuddin, Amir. Ushul Fiqh, Jilid 2, Cet. Ke-V, (Jakarta: Kencana, 2011).

Tjiptono, Fandy. Manajemen Jasa, (Yogyakarta: Andi, 2006

Yulianita, Neny. Dasar-Dasar Public Relation.

Bandung: Pusat penerbitan Bandung. 2005 
Zahrah, Muhammad Abu. Târîkh al-Madzâhib alIslâmiyah. Kairo: Dâr alFikr al-Arabî. Tt

Zahrah, Muhammad Abû.

Ushûl al-Fîqh. Mesir:

Dâr al-Fikr al-'Arabi. 1958

Zaid, Musthafâ. Nazhariyat al-Mashlahah fî atTasyrî́ al-Islâmî. Kairo:

Dâr al-Yasr. Tt

Zidan, Abdul Karim. AlWajiz fii Ushul Fiqh. Cet VII.

Baghdad:

Muassasah Qurthubah. 1976

Disertation and Thesis:

A'yuni, Qurrotul. Strategi Promosi Madrasah

Ibtidaiyah

Muhammadiyah (MIM) Gatak dalam

Meningkatkan Jumlah Siswa. Surakarta: pascasarjana IAIN Surakarta. 2015

Al-'Atibi, Badr Mabruk.

Taswiq al-Khidmat alJami'iyyah wa dauruhu fi tahsini al-qudroh attanafisiyyah li al-Jami'ah as-Su'udiyyah.

Mutathollib takmily linaili darojati aldukturoh fi Qismi idaroh at-tarbiyyah wa attakhthith fi kulliyat at-
Tarbiyyah fi Jami'ah Ummu al-Quro AsSu'udiyyah, 2015.

As-Sulamî, Hâmid Jâbir. AlIstishlâh 'inda Syaikh alIslâm Ibn Taimiyah. Tesis. Madinah: Jâmi'ah Umm al-Qurâ. 1989

Fathonah, Kuni. Strategi Pemasaran Jasa

Pendidikan dalam

Meningkatkan

Pelayanan Pendidikan di MAN I Sragen.

Surakarta: Pascasarjana IAIN Surakarta. 2016

Fatkuraji. Pengembangan

Model Manajemen

Pemasaran berbasis

Layanan Pendidikan

Madrasah Tsanawiyah

Swasta di Kota

Semarang. Disertasi

Program Pascasarjana

Program Studi

Manajemen

Kependidikan

Universitas Negeri

Semarang. 2016

Nugroho, Anggi Septia.

Manajemen Pemasaran

Pendidikan dalam

Meningkatkan Mutu PAI

di SMA 2

Muhammadiyah

Yogyakarta. Yogyakarta:

UIN Sunan Kalijaga.

2014 